\title{
МЕТОДИКА ПРОВЕДЕНИЯ ЗАНЯТИЙ В КРУЖКАХ ПО ХИМИИ В ОБЩЕОБРАЗОВАТЕЛЬНЫХ ШКОЛАХ
}

\author{
Гюль Невзад Ахмед \\ докторант \\ Институт Образования \\ Азербайджанской Республики
}

Аннотация: В настоящее время важную роль играют занятия кружков по химии, которые является одним из основных видов внеклассной работы и играют ключевую роль в реализации политехнического образования в общеобразовательных школах. Так как невозможно найти место производства, которое прямо или косвенно не было связано с химией и не использует химические процессы. Среди основных форм внеклассной работы по химии важное место занимают занятия в кружках с определенной группой учеников. При организации кружка по химии, необходимо учитывать уровень знаний, желание и интерес учеников. На наш взгляд, кружок по химии должен охватывать как можно больше учеников.

Ключевые слова: Внеклассная работа, занятия в кружках, интересы учащихся, общеобразовательная школа.

\section{METHODOLOGY OF ORGANIZING CHEMISTRY CLUB CLASSES IN SECONDARY SCHOOLS}

\section{Gul Nevzat Ahmet}

\begin{abstract}
At present, the classes of the chemistry club, which is one of the main types of extracurricular activities or play a key role in the implementation of polytechnic education in our schools, play an important role. Because it is impossible to find a field of production which is not directly or indirectly related to chemistry and does not use chemical processes. Among the main forms of extracurricular activities in chemistry, club classes with a certain group of students have an important role. Students' level of knowledge, desire and interest must be taken into account when organizing a chemistry club. In our opinion, the chemistry club should cover the students with the same level.
\end{abstract}


Key words: Extracurricular activities, classes in clubs, students' interests, secondary school.

В современный период содержание образования следует определять таким образом, чтобы оно служило развитию у ученика осознания, понимания причин событий и умения принимать правильные решения. Поэтому учебный процесс следует строить в соответствии с интересами и потребностями ученика, уровнем его знаний, возможностей и способностей, а также следует отдавать предпочтение использованию активных методов обучения на уроках, лишь таким образом можно развить у учащихся навыки, необходимые для жизни. Построение учебного процесса, основанного на современных принципах обучения, поможет учащимся приобрести следующие навыки: получить наиболее важную информацию, взаимодействовать друг с другом, выполнять индивидуальную работу, самостоятельно получать знания посредством исследования, собирать информацию, применять полученные знания и умения в жизни.

Основная цель внеклассных занятий по химии - углубить и расширить знания учащихся, повысить их интерес к химии, развить их самостоятельность и творческие способности.

В настоящее время важную роль играют занятия в кружке по химии, который является одним из основных видов внеклассной работы или играет ключевую роль в реализации политехнического образования в наших школах. Потому что невозможно найти место производства, которое прямо или косвенно не было бы связано с химией и не использовало бы химические процессы. Чем более организованы занятия в кружке, тем они привлекательнее для учеников и тем больше у них энтузиазма. Среди основных форм внеклассной работы по химии важное место занимают занятия в кружках с определенной группой учеников. При организации кружка по химии, необходимо учитывать уровень знаний, желание и интерес учеников. На наш взгляд, кружок по химии должен охватывать как можно больше учеников. Поскольку кружок по химии охватывает учеников разных возрастных категорий, тематика занятий в кружке не может совпадать. Темы определяются учителем с учетом пожеланий учеников. Созданный под руководством учителя кружок по химии должен работать непрерывно и долгое время. Даже по прошествии многих лет, с одной стороны, необходимо привлекать в клуб новых учеников, с другой стороны, учеников, окончивших школу и покинувших клуб, 
необходимо заменить. В некоторых случаях молодые энтузиасты химии не разрывают связи с кружком по химии, членом которого они являются, даже после окончания учебы. Можно с уверенностью сказать, что школьный кружок по химии - это база для подготовки целеустремленных химиков. К сожалению, в некоторых школах кружок по химии создается в начале каждого учебного года и закрывается в конце учебного года, когда ученики уходят на летние каникулы. Считаем это серьезным недостатком в деятельности кружка. Это свидетельствует о том, что содержание работы кружка неудовлетворительно. Нормальная творческая работа кружка по химии обычно настолько привлекает учеников, что даже во время летних каникул они временно покидают клуб с большим сожалением.

Для организации кружка по химии в общеобразовательных школах, прежде всего, необходимо назначить руководителя клуба и создать группу из нескольких инициаторов, которые больше всего заинтересованы в химии и хотят приобрести жизненно важные умения и навыки. Каждый член инициативной группы занимается тем или иным вопросом в течение определенного периода времени. Таким образом, он информирует учащихся VII-XI классов о роли и значении химической науки в промышленности, сельском хозяйстве, покорении космоса, решении проблемы искусственного питания и так далее. В результате ученики начинают интересоваться предметом химия и, в целом, химической наукой, только после этого инициативная группа должна объявить об организации кружка по химии в школе и широко продвигать цели, задачи и основное содержание кружка в той области, которые он будет охватывать.

Дисциплина в организации и проведении кружков - одно из главных условий успеха занятий в кружке, а также своевременной и хорошей подготовки каждого члена к любой без исключения задаче и выполнения всех мероприятий в соответствии с планом.

На первом занятии руководитель кружка должен распределить темы лекций и практических занятий между членами кружка в течение года, установить конкретный день для каждого из них, провести общие и индивидуальные консультационные дни для учеников и составить план по каждой теме и практической работе, указать литературу, которую они будут использовать. 
Чтобы получить ожидаемый результат от занятий в кружках по химии, перед нами ставятся следующие задачи.

1. В общеобразовательной школе каждое занятие в кружке в первую очередь служит укреплению материала, углублению и расширению знаний, связанных с темой в классе.

2. Создает основу для обучения учащихся, как применять знания, полученные на уроках, в жизни и в различных сферах производства.

3. Развивает общественно-политическую активность учащихся и их собственную активность.

4. Привлекает школьников к активному участию в общественной жизни и творческой работе, происходящей в нашей стране.

5. Стремиться организовать культурный отдых и интеллектуальные развлечения, которые вдохновят учащихся проявить интерес к уроку.

Из всего вышеуказанного следует, что занятия в кружках химии должны быть подчинены общеобразовательной работе школы. Для достижения вышеуказанных целей члены кружка должны изучать природные ресурсы Азербайджана, химическое сырье, способы их использования, мощную химическую промышленность, способы, как получать различные продукты из местного сырья (йод, бром, бромид калия, этиловый спирт, различные реагенты и т. д.). Изготовить различные наглядные пособия (схемы, стенды и др.) для химического кабинета, синтезировать недостающие реагенты, подготовить приборы.

Члены кружка должны также организовывать научные доклады по актуальным проблемам современной химии, жизни и деятельности выдающихся азербайджанских химиков (Ю.Г. Мамедалиев, М.Ф. Нагиев, А.М. Гулиев и др.), организовывать вечера химии, издавать полезную для школы газету и бюллетень «Юный химик» и так далее.

\section{Список литературы}

1. Аббасов М.М., Гюнджегёрю Н.А. Свойства катализаторов: принципы и виды катализа. / Сборник статей Х Международная конференция Развития науки в XXI веке, 4 часть, 15 феврал, 2016, с.64-66

2. Владер Ю.М. Как развивать внимание // Химия в школе, 2001, №1, c. 16-20. 
3. Гузеев В.В. Организационные формы обучения и уроков // Химия в школе. 2002, №4, с. 22-28.

4. Гюнджегори Н.А. Принципы общего решения стандартных задач по химии//Вісник Хмельницького Національного Університета. 2016, №3, с.26-32. 